Nisbayanti, Aisyah Novianti dan Nurul Astuti Rahmadani
Dampak Penggunaan Media Phet dan Alat Peraga Praktikum terhadap Pemahaman Konsep Getaran Harmonik Sederhana pada Siswa SMA

\title{
DAMPAK PENGGUNAAN MEDIA PHET DAN ALAT PERAGA PRAKTIKUM TERHADAP PEMAHAMAN KONSEP GETARAN HARMONIK SEDERHANA PADA SISWA SMA
}

\section{THE IMPACT OF THE USE OF PHET MEDIA AND PRACTICAL TOOLS TO THE UNDERSTANDING OF THE CONCEPT OF SIMPLE HARMONIC VIBRATION IN HIGH SCHOOL STUDENTS}

\author{
Nisbayanti $^{1}$, Aisyah Novianti ${ }^{2}$, Nurul Astuti Rahmadani ${ }^{3}$ \\ Pendidikan Ekonomi, Ekonomi ${ }^{1}$ Pendidikan IPA, MIPA ${ }^{2}$ Pendidikan Fisika, MIPA ${ }^{3}$ \\ ${ }^{1,2,3}$ Universitas Negeri Makassar \\ nisbayanti1470@gmail.com ${ }^{1}$
}

\begin{abstract}
The purpose of this study was to determine the impact of the use of PhET media and practical tools on understanding the concept of simple harmonic vibrations in high school students. This type of research is a quasi-experimental with non-equivalent group design. This research was conducted at SMAN 1 Gowa in class X MIA 3 using PhET media and class X MIA 1 using practical tools based on systematic sampling techniques. The results showed an increase in understanding of concepts using PhET media. From the results of the study it was also evident that the increase in understanding of using practical tools.
\end{abstract}

Keywords: practical tools, simple harmonic vibration, PhET media, understanding concepts

\section{Abstrak}

Tujuan penelitian ini adalah untuk mengetahui dampak apenggunaan media PhET dan alat peraga praktikum terhadap pemahaman konsep getaran harmonik sederhana pada siswa SMA. Jenis penelitian ini adalah kuasi eksperimen dengan non-equivalent group design. Penelitian dilakukan di SMAN 1 Gowa pada kelas X MIA 3 menggunakan media PhET dan kelas X MIA 1 menggunakan media alat peraga berdasarkan pada teknik sampling sistematis. Hasil penelitian menunjukkan terjadi peningkatan pemahaman konsep menggunakan media PhET. Dari hasil penelitian juga menunjukkan bahwa terjadi peningkatan pemahaman konsep dengan menggunakan media alat peraga praktikum.

Kata Kunci: getaran harmonik sederhana, media PhET, media alat peraga praktikum, pemahaman konsep

\section{PENDAHULUAN}

Rata-rata skor pencapaian peserta didik Indonesia untuk bidang sains berada di peringkat ke 62 dari 69 negara yang dievaluasi. Berdasarkan dari data Programme for International Student Assessment (PISA) tahun 2018, dalam hal pemahaman terhadap sains, Indonesia berada pada level 1 dengan pencapaian skor hanya sebesar 396 jauh dari China yang menempati urutan teratas dengan capaian skor mencapai 590 [1]. Hal ini dikarenakan pembelajaran sains salah satunya fisika bukan hanya terdiri dari kumpulan pengetahuan yang membahas mengenai fakta, konsep, atau prinsip saja, tetapi mengharuskan peserta dapat memahami secara khusus fenomena-fenomena yang terjadi di alam. Khususnya pada materi gerak harmonik sederhana. 
Nisbayanti, Aisyah Novianti dan Nurul Astuti Rahmadani
Dampak Penggunaan Media Phet dan Alat Peraga Praktikum terhadap Pemahaman Konsep Getaran Harmonik Sederhana pada Siswa SMA
Salah satu hasil penelitian menyatakan bahwa lebih banyak peserta didik yang mengalami miskonsepsi pada materi gerak harmonik sederhana dibanding dengan peserta didik yang paham konsep secara utuh [2]. Berkenaan dengan hal tersebut juga terdapat penelitian lain yang mendapatkan hasil serupa pada tingkat yang lebih tinggi yaitu pemahaman atau penguasaan konsep mahasiswa program studi pendidikan fisika Universitas Sriwijaya pada pokok bahasan gerak harmonik sederhana dinilai masih rendah, hal ini dibuktikan dengan diperolehnya skor pemahaman atau penguasaan konsep mahasiswa sebesar 28,21\% [3]. Dari data tersebut jelas bahwa pemahaman terkait komsep gerak harmonik sederhana masih kurang. Oleh karena itu, untuk lebih meningkatkan pemahaman peserta didik dalam memahami materi fisika maka di setiap sekolah disediakan laboratorium sebagai wadah dalam melakukan suatu praktikum untuk memudahkan peserta didik dalam memahami materi khususnya materi gerak harmonik sederhana.

Menurut data Pokok Pendidikan Dasar dan Menengah Kementrian Pendidikan dan Kebudayaan tahun 2019/2020 menyatakan jumlah Sekolah Menengah Atas di Sulawesi Selatan sebanyak 580 [4]. Namun jumlah laboratorium fisika di sekolah hanya sebanyak 221 [5]. Hal tersebut menunjukkan bahwa tidak semua sekolah di Sulawesi Selatan memiliki fasilitas laboratorium. Salah satu sekolah SMA di Sulawesi Selatan yang memiliki masalah terkait dengan laboratorium adalah SMAN 1 Gowa dengan kendala dari segi pengadaan alat peraga. Minimnya fasilitas alat peraga dalam laboratorium mengakibatkan siswa terkendala ketika akan melakukan praktikum. Hal ini juga menjadi alasan umum seorang guru hanya menerangkan dengan ceramah, diskusi, dan penyelesaian soal tanpa eksperimen [2]. Salah satu solusi yang ditawarkan yaitu dengan menggunakan media PhET Simulation, yaitu sebuah media belajar yang interaktif dan dapat membantu peserta didik dalam memahami materi yang disampaikan [6]. Hasil penelitian yang dilakukan oleh Ref. [7] terkait peningkatan pemahaman peserta didik kelas XI MIPA SMAN 1 Krangkeng pada materi gerak hamonik sederhana melalui media virtual lab (PhET) menunjukkan terjadinya peningkatan pemahaman konsep dengan peningkatan hasil belajar sebesar 12,78\%. Dari data tersebut memperlihatkan penggunaan media PhET Simulation juga berpengaruh terhadap peningkatan pemahaman peserta didik dalam materi fisika khususnya gerak harmonik sederhana [8].

\section{METODE PENELITIAN}

Jenis penelitian yang digunakan adalah kuantitatif. dengan pendekatan kuasi eskperimen. Desain penelitian yang digunakan pada penelitian ini adalah desain penelitian Non-Equivalent Group Design seperti pada tabel 1 di bawah ini

Tabel 1. Desain Penelitian

\begin{tabular}{llll}
\hline Kelompok & $\begin{array}{l}\text { Pre } \\
\text { test }\end{array}$ & Perlakuan & $\begin{array}{l}\text { Post } \\
\text { test }\end{array}$ \\
\hline Eksperimen & $\mathbf{T}_{\mathbf{1}}$ & $\mathbf{X}_{\mathbf{1}}$ & $\mathbf{T}_{\mathbf{2}}$ \\
I & & & \\
$\begin{array}{l}\text { Eksperimen } \\
\text { II }\end{array}$ & $\mathbf{T}_{\mathbf{3}}$ & $\mathbf{X}_{\mathbf{2}}$ & $\mathbf{T}_{\mathbf{4}}$ \\
\hline
\end{tabular}

Keterangan :

Eksperimen $\mathrm{I}=$ Kelas eksperimen dengan media PhET Simulations

Eksperimen II $=$ Kelas eksperimen dengan media alat peraga

$\mathrm{X}_{1}=$ Perlakuan dengan media PhET untuk kelas eksperimen I

$\mathrm{X}_{2}=$ Perlakuan dengan alat peraga praktikum untuk kelas eksperimen II

$\mathrm{T}_{1}=$ Hasil pre test kelas eksperimen I

$\mathrm{T}_{2}=$ Hasil post test kelas eksperimen I

$\mathrm{T}_{3}=$ Hasil pre test kelas eksperimen II

$\mathrm{T}_{4}=$ Hasil post test kelas eksperimen II

Teknik pengumpulan data yang digunakan dalam penelitian ini yaitu dengan 
Nisbayanti, Aisyah Novianti dan Nurul Astuti Rahmadani
Dampak Penggunaan Media Phet dan Alat Peraga Praktikum terhadap Pemahaman Konsep Getaran Harmonik Sederhana pada Siswa SMA menggunakan tes pemahaman konsep pada materi getaran harmonik sederhana yang disusun berdasarkan indikator pemahaman konsep, meliputi kegiatan menafsirkan (interpreting), mencontohkan (exemplifying), mengklasifikasikan (classifying), dan membandingkan (comparing). Tes dilakukan sebelum dan setelah kelas eksperimen diberi perlakuan.

Populasi dalam penelitian ini yaitu siswa kelas X SMAN 1 Gowa. Teknik pengambilan sampel yang digunakan adalah teknik sampling sistematis. Analisis data yang digunakan yaitu analisis deskriptif komparatif untuk menjelaskan data dengan cara mendeskripsikan atau menggambarkan perbandingan antara dua kelompok sampel atau lebih dalam sebuah populasi.

Analisis Statistik Inferensial terdiri dari uji hipotesis. Pengajuan hipotesis yang dimaksud yaitu untuk melihat apakah ada perbedaan pemahaman konsep peserta didik kelas eksperimen I dan eksperimen II yang diberi perlakuan dengan sistem PhET dan alat peraga praktikum pada materi getaran harmonik sederhana. Pengujian dilakukan menggunakan independent sample t-test. Adapun kriteria pengujiannya adalah jika $\mathrm{p}_{\text {value }}<\alpha=0,05$ maka $\mathrm{H}_{\mathrm{o}}$ ditolak, sedangkan jika $\mathrm{p}_{\text {value }} \geq=\alpha=0,05$ maka $\mathrm{H}_{\mathrm{o}}$ diterima. Hipotesis statistik yang diuji adalah:

$\mathrm{H}_{0}: \mu 1=\mu 2$ melawan $\mathrm{H}_{1}: \mu 1 \neq \mu 2$

Keterangan:

$\mu 1=$ Rata-rata hasil kelas $\mathrm{X}$ dengan menggunakan media PhET.

$\mu 2=$ Rata-rata hasil belajar siswa kelas $\mathrm{X}$ dengan menggunakan alat peraga praktikum.

\section{HASIL DAN PEMBAHASAN}

A. Analisis Data Deskriptif
1. Pre test

Tabel 2. Analisis Deskriptif Pre test Kelas Eksperimen 1 dan Kelas Eksperimen 2

\begin{tabular}{|c|c|c|c|c|}
\hline & \multicolumn{4}{|c|}{ Descriptive Statistics } \\
\hline & $\mathrm{N}$ & $\begin{array}{l}\text { Mini } \\
\text { mum }\end{array}$ & $\begin{array}{l}\text { Maxi } \\
\text { mum }\end{array}$ & Mean \\
\hline & Statistic & $\begin{array}{l}\text { Statis } \\
\text { tic }\end{array}$ & $\begin{array}{l}\text { Statis } \\
\text { tic }\end{array}$ & $\begin{array}{l}\text { Stati Std. } \\
\text { stic Error }\end{array}$ \\
\hline Kelas & 26 & 15 & 50 & $34,2 \quad 2,070$ \\
\hline $\begin{array}{l}\text { Eksperime } \\
\text { n I }\end{array}$ & & & & 3 \\
\hline Kelas & 25 & 10 & 50 & $30,21,947$ \\
\hline $\begin{array}{l}\text { Eksperime } \\
\mathrm{n} \text { II }\end{array}$ & & & & 0 \\
\hline $\begin{array}{l}\text { Valid N } \\
\text { (listwise) }\end{array}$ & 25 & & & \\
\hline
\end{tabular}

Tabel di atas menunjukkan bahwa ratarata nilai pre test kelas eksperimen 1 lebih tinggi daripada kelas eksperimen 2 namun perbedaannya tidak besar. Minimum hampir sama, dan nilai maksimum sama.

2. Pos test

Tabel 3. Analisis Deskriptif Pos-test Kelas Eksperimen 1 dan Kelas Eksperimen 2

\begin{tabular}{lccccc}
\hline \multicolumn{5}{c}{ Descriptive Statistics } \\
& \multicolumn{5}{c}{ Max } \\
& N & Mini & imu & \\
& & & & & Std. \\
& Statisti & Statis & Stati & Stati & Erro \\
& c & tic & stic & stic & r \\
\cline { 2 - 6 } & 26 & 10 & 70 & 41,9 & 3,32 \\
Kelas & & & & 2 & 9 \\
Eksperi & & & & & \\
men 1 & & & & & \\
\hline Kelas & 25 & 20 & 70 & 47,4 & 2,81 \\
Eksperi & & & & 0 & 5 \\
men 2 & & & & & \\
\hline Valid N & 25 & & & & \\
(listwise) & & & & & \\
\hline
\end{tabular}

Nilai rata-rata kelas eksperimen 1 lebih kecil daripada kelas eksperimen 2. Hal ini menunjukkan bahwa pemahaman konsep pada kelas eksperimen 2 lebih besar daripada kelas eksperimen 1.

Adapun data ketercapaian tiap indikator pemahaman konsep pada pre test dit 
Nisbayanti, Aisyah Novianti dan Nurul Astuti Rahmadani
Dampak Penggunaan Media Phet dan Alat Peraga Praktikum terhadap Pemahaman Konsep Getaran Harmonik Sederhana pada Siswa SMA ampilkan pada tabel sedangkan pada post test ditampilkan pada tabel.

Tabel 4. Ketercapaian Indikator Pemahaman Konsep Berdasarkan Data Pre test Kelas Eksperimen 1 dan Kelas Eksperimen 2.

\begin{tabular}{|c|c|c|c|}
\hline \multirow{2}{*}{$\begin{array}{l}\mathbf{N} \\
\mathbf{0}\end{array}$} & \multirow{2}{*}{$\begin{array}{c}\text { Indikato } \\
\mathbf{r}\end{array}$} & \multicolumn{2}{|c|}{$\begin{array}{c}\text { Presentase }(\%) \text { dan } \\
\text { Kategori }\end{array}$} \\
\hline & & $\begin{array}{l}\text { Eksperim } \\
\text { en } 1\end{array}$ & $\begin{array}{l}\text { Eksperim } \\
\quad \text { en } 2\end{array}$ \\
\hline 1. & $\begin{array}{l}\text { Meng- } \\
\text { klasifikas } \\
\text { ikan }\end{array}$ & $\begin{array}{c}18.59 \\
\text { (Kurang } \\
\text { Sekali) }\end{array}$ & $\begin{array}{c}20.67 \\
\text { (Kurang) }\end{array}$ \\
\hline 2. & $\begin{array}{l}\text { Menjelas } \\
\text { kan }\end{array}$ & $\begin{array}{c}42.86 \\
\text { (Cukup) }\end{array}$ & $\begin{array}{c}41.71 \\
\text { (Cukup) }\end{array}$ \\
\hline 3. & $\begin{array}{l}\text { Mencont } \\
\text { ohkan }\end{array}$ & $\begin{array}{c}38.46 \\
\text { (Kurang) }\end{array}$ & $\begin{array}{c}49.33 \\
\text { (Cukup) }\end{array}$ \\
\hline 4. & $\begin{array}{l}\text { Menafsir } \\
\text { kan }\end{array}$ & $\begin{array}{c}35.58 \\
\text { (Kurang) }\end{array}$ & $\begin{array}{c}20.00 \\
\text { (Kurang) }\end{array}$ \\
\hline & $\begin{array}{l}\text { ntase } \\
\text { Rata }\end{array}$ & $\begin{array}{c}33.85 \\
\text { (Kurang) }\end{array}$ & $\begin{array}{c}\text { 32.93 } \\
\text { (Kurang) }\end{array}$ \\
\hline
\end{tabular}

Tabel 5. Ketercapaian Indikator Pemahaman Konsep Berdasarkan Data Pos test Kelas Eksperimen 1 dan Kelas Eksperimen 2.

\begin{tabular}{|c|c|c|c|}
\hline \multirow[t]{2}{*}{$\begin{array}{c}\mathbf{N} \\
\mathbf{0}\end{array}$} & \multirow[t]{2}{*}{ Indikator } & \multicolumn{2}{|c|}{$\begin{array}{c}\text { Presentase (\%) dan } \\
\text { Kategori }\end{array}$} \\
\hline & & $\begin{array}{l}\text { Eksperim } \\
\text { en } 1\end{array}$ & $\begin{array}{l}\text { Eksperim } \\
\quad \text { en } 2\end{array}$ \\
\hline 1. & $\begin{array}{l}\text { Meng- } \\
\text { klasifikasik } \\
\text { an }\end{array}$ & $\begin{array}{c}32.69 \\
\text { (Kurang) }\end{array}$ & $\begin{array}{c}23.33 \\
\text { (Kurang) }\end{array}$ \\
\hline 2. & $\begin{array}{l}\text { Menjelaska } \\
\mathrm{n}\end{array}$ & $\begin{array}{c}56.04 \\
\text { (Cukup) }\end{array}$ & $\begin{array}{l}65.71 \\
\text { (Baik) }\end{array}$ \\
\hline 3. & $\begin{array}{l}\text { Mencontoh } \\
\text { kan }\end{array}$ & $\begin{array}{c}47.44 \\
\text { (Cukup) }\end{array}$ & $\begin{array}{c}40.00 \\
\text { (Kurang) }\end{array}$ \\
\hline 4. & $\begin{array}{l}\text { Menafsirka } \\
\mathrm{n}\end{array}$ & $\begin{array}{c}34.62 \\
\text { (Kurang) }\end{array}$ & $\begin{array}{c}54.00 \\
\text { (Cukup) }\end{array}$ \\
\hline & $\begin{array}{l}\text { entase } \\
\text { a-Rata }\end{array}$ & $\begin{array}{c}42.70 \\
\text { (Cukup) }\end{array}$ & $\begin{array}{c}\text { 45.76 } \\
\text { (Cukup) }\end{array}$ \\
\hline
\end{tabular}

Sedangkan data pemahaman siswa terhadap materi getaran harmonik sederhana pada kelas eksperimen 1 dan 2 berdasarkan skala CRI adalah sebagai berikut:

Tabel 6. Pemahaman Kelas X MIA 1 SMAN 1 Gowa berdasarkan CRI

\begin{tabular}{|c|c|c|}
\hline No soal & Indikator & $\begin{array}{c}\text { Kategori } \\
\text { (dalam } \\
\%)\end{array}$ \\
\hline
\end{tabular}

\begin{tabular}{|c|c|c|c|}
\hline & \multicolumn{2}{|c|}{ Paham } \\
\hline & & $\begin{array}{l}\text { Pre } \\
\text { test }\end{array}$ & $\begin{array}{l}\text { Pos } \\
\text { test }\end{array}$ \\
\hline \multirow{7}{*}{$\begin{array}{c}1,3,4,6,8,9 \\
2,5,10,11,13 \\
18,20 \\
7,17,19 \\
12,14,15,16\end{array}$} & Mengklasifik & 7.3 & 22 \\
\hline & asikan & 3 & 44 \\
\hline & Menjelaskan & 25. & 28 \\
\hline & Mencontohka & 71 & 37 \\
\hline & & 17. & \\
\hline & Menafsirkan & 33 & \\
\hline & & 5 & \\
\hline \multirow{2}{*}{\multicolumn{2}{|c|}{ Rata-rata }} & 13. & 32. \\
\hline & & 84 & 75 \\
\hline \multicolumn{4}{|c|}{$\begin{array}{l}\text { Tabel 7. Pemahaman Kelas X MIA } 3 \\
\text { SMAN } 1 \text { Gowa berdasarkan CRI }\end{array}$} \\
\hline \multirow{3}{*}{ No soal } & \multirow{3}{*}{ Indikator } & \multirow{2}{*}{\multicolumn{2}{|c|}{$\begin{array}{c}\text { Kategori } \\
\text { (dalam } \\
\% \text { ) } \\
\text { Paham }\end{array}$}} \\
\hline & & & \\
\hline & & $\begin{array}{l}\text { Pre } \\
\text { test }\end{array}$ & $\begin{array}{l}\text { Pos } \\
\text { test }\end{array}$ \\
\hline \multirow{8}{*}{$\begin{array}{c}1,3,4,6,8,9 \\
2,5,10,11,13 \\
18,20 \\
7,17,19 \\
12,14,15,16\end{array}$} & Mengklasifik & 6.4 & 16. \\
\hline & asikan & 1 & 67 \\
\hline & Menjelaskan & 24. & 34. \\
\hline & Mencontohka & 71 & 62 \\
\hline & $\mathrm{n}$ & 16. & 28. \\
\hline & Menafsirkan & 67 & 21 \\
\hline & & 5.7 & 18. \\
\hline & & 7 & 27 \\
\hline \multicolumn{2}{|l|}{ Rata-rata } & $\begin{array}{l}13 . \\
39\end{array}$ & $\begin{array}{l}24 . \\
44\end{array}$ \\
\hline
\end{tabular}

Berdasarkan dari kedua tabel tersebut menunjukkan bahwa antara hasil pre test dari kedua kelas yang dijadikan sebagai kelas eksperimen tidak menunjukkan perbedaan yang berarti, lain halnya dengan hasil pos test menunujukkan selisih perbedaan yang cukup jauh.

\section{B. Analisis Data Inferensial}

Hasil uji hipotesis pemahaman konsep kelas eksperimen 1 menunjukkan bahwa terdapat perbedaan antara sebelum dan sesudah pembelajaran dengan menggunakan $P h E T$. Karena mean bernilai negatif, artinya terjadi kecenderungan peningkatan pemahaman konsep sesudah perlakuan. Rata-rata peningkatannya adalah 7,692. Sedangkan hasil uji hipotesis pemahaman 
Nisbayanti, Aisyah Novianti dan Nurul Astuti Rahmadani
Dampak Penggunaan Media Phet dan Alat Peraga Praktikum terhadap Pemahaman Konsep Getaran Harmonik Sederhana pada Siswa SMA konsep kelas eksperimen 2 menunjukkan bahwa terdapat perbedaan antara sebelum dan sesudah pembelajaran dengan menggunakan alat peraga. Karena mean bernilai negatif, artinya terjadi kecenderungan peningkatan pemahaman konsep sesudah perlakuan. Rata-rata peningkatanya adalah 17,200. Sedangkan untuk perbedaan sampelnya diperoleh $\mathrm{sig}=$ 0,186, ini berarti bahawa tidak ada perbedaan pos-test anatara kelas eksperimen 1 dengan menggunakan PhET Simulation dan kelas eksperimen 2 dengan menggunakan alat peraga.

1. Pemahaman Konsep Peserta didik pada materi Getaran Harmonik Sederhana dengan Menggunakan Media PhET Simulation

Berdasarkan dari hasil penelitian yang telah dilakukan, rata-rata pencapaian indikator pemahaman konsep pada saat pretest menunjukkan angka $33,85 \%$ yang meliputi kemampuan mengklasifikasikan sebesar 18.59\%berada pada kategori kurang sekali, kemampuan menjelaskan sebesar $42,86 \%$, berada pada kategori cukup. Kemapmuan mencontohkan 38,46\% yang berada pada kategori kurang dan kemampuan menafsirkan sebesar $35.58 \%$ yang berada pada kategori kurang. Sehingga rata-rata yang ditunjukkan dalam pencapaian indikator ditunjukkan dalam kategori kurang.

Setelah diberikan materi mengenai Getaran Harmonik Sederhana dengan menggunakan media PhET Simulation dan dilakukan pos-test, menunjukkan rata-rata pencapaian indikator peserta didik sebesar $42.70 \%$ dan tergolong dalam kategori cukup. Hal ini meliputi, kemampuan mengklasifikasikan sebesar $32.69 \%$, menjelaskan sebesar $56.04 \%$, mencontohkan sebesar $47.44 \%$ dan kemampuan menafsirkan sebesar 34.62 dan berada pada ketegori cukup.
Dengan melihat hasil persentasi dari setiap indikator pencapaian pemahaman konsep rata-rata pencapaian indikator pemahaman konsep peserta didik terlihat adanya perbedaan pemahaman peserta didik pada saat dilakukan pre test dan saat setelah dilakukan pos test. Hal ini dapat dilihat dari persentase rata-rata pencapaian pemahaman konsep dari beberapa indikator di atas yaitu pada saat pre test sebesar $33,85 \%$ dan pada saat setelah pos test rata-rata persentase menjadi $42.70 \%$.

Berdasarkan hasil uji hipotesis pemahaman konsep siswa terhadap materi getaran harmonik sederhana menunjukkan adanya perbedaan antara sebelum dan sesudah pembelajaran menggunakan PhET dengan sig = 0.016. selain itu, uji hipotesis ini juga menunjukkan adanya kecenderungan peningkatan pemahaman konsep setelah perlakuan dengan rata-rata peningkatan sebesar 7.692. Dari data tersebut memperlihatkan penggunaan media PhET Simulation juga berpengaruh terhadap peningkatan pemahaman peserta didik dalam materi fisika khususnya gerak harmonik sederhana.

2. Pemahaman Konsep Peserta didik pada materi Getaran Harmonik Sederhana dengan Menggunakan Media Alat Peraga

Berdasarkan dari hasil penelitian yang telah dilakukan, rata-rata pencapaian indikator pemahaman konsep pada saat pre test menunjukkan angka $32.93 \%$ yang meliputi kemampuan mengklasifikasikan sebesar $20.67 \%$ berada pada kategori kurang sekali, kemampuan menjelaskan sebesar $41.71 \%$, berada pada kategori cukup, kemampuan mencontohkan $49.33 \%$ yang berada pada kategori kurang dan kemampuan menafsirkan sebesar $20.00 \%$ yang berada pada kategori kurang. Sehinggan rata-rata yang 
Nisbayanti, Aisyah Novianti dan Nurul Astuti Rahmadani
Dampak Penggunaan Media Phet dan Alat Peraga Praktikum terhadap Pemahaman

Konsep Getaran Harmonik Sederhana pada Siswa SMA ditunjukkan dalam pencapaian indikator ditunjukkan dalam kategori kurang.

Setelah diberikan materi mengenai Getaran Harmonik Sederhana dengan menggunakan media PhET Simulation dan dilakukan pos-test, menunjukkan rata-rata pencapaian indikator peserta didik sebesar $45.76 \%$ dan tergolong dalam kategori cukup. Hal tersebut meliputi, kemampuan mengklasifikasikan sebesar $23.33 \%$, kemampuan menjelaskan sebesar $65.71 \%$, mencontohkan sebesar $40.00 \%$ dan kemampuan menafsirkan sebesar $54.00 \%$ sehingga berada pada ketegori cukup. Dengan melihat hasil persentasi dari setiap indikator pencapaiana pemahaman konsep, rata-rata pencapaian indikator pemahaman konsep pada peserta didik terlihat adanya perbedaan pemahaman pada saat dilakukan pre test dan saat setelah dilakukan pos test. Hal ini dapat dilihat dari persentase rata-rata pencapaian pemahaman konsep dari beberapa indikator di atas yaitu pada saat pre test sebesar $33,93 \%$ dan pada saat setelah pos test rata-rata persentase menjadi $45.76 \%$.

Berdasarkan hasil uji hipotesis pemahaman konsep siswa terhadap materi getaran harmonik sederhana menunjukkan adanya perbedaan antara sebelum dan sesudah pembelajaran menggunakan alat peraga dengan sig = 0.186. Selain itu, uji hipotesis ini juga menunjukkan adanya kecenderungan peningkatan pemahaman konsep setelah perlakuan dengan rata-rata 17.200. peningkatan sebesar 7.692. Dari data tersebut memperlihatkan penggunaan media PhET Simulation juga berpengaruh terhadap peningkatan pemahaman konsep peserta didik dalam materi fisika khususnya gerak harmonik sederhana.
3. Perbandingan Pemahaman Konsep antara Penggunaan Media PhET dengan Alat Peraga Praktikum

Dalam mengukur perbandingan pemahaman antara siswa kelas X MIA 1 dan MIA 3 pada materi getaran harmonik sederhana, dilakukan dengan cara menentukan jumlah setiap siswa yang paham ditinjau dari dua kriteria yaitu jawaban yang benar disertai dengan skala CRI (Certainty of Response Index) dari setiap nomor pada soal tes pre test dalam bentuk pilihan ganda. Skala CRI berfungsi untuk mengukur derajat kepastian siswa dalam menyelesaikan konsep getaran harmonik sederhana. Jika skala CRI rendah (skala 0-2), ini menunjukkan bahwa siswa menjawab soal hanya berdasarkan perkiraan baik jawaban itu benar atau salah. Hal tersebut dapat digunakan sebagai petunjuk dalam mengetahui kekurangan pengetahuan siswa. Apabila skala CRI tinggi (skala 3-5), ini menunjukkan kepercayaan yang tinggi pada hukum dan metode yang digunakan untuk sampai pada jawaban. Bila jawaban itu benar, menunjukkan kebenaran menerapkan pengetahuannya dalam menyelesaikan persoalan yang dihadapinya. Apabila jawaban itu salah, ini menunjukkan kesalahan dalam menerapkan pengetahuannya dalam menyelesaikan persoalan yang dihadapinya.

Hasil pre test siswa antara kelas $\mathrm{X}$ MIA 1 dan MIA 3 menunjukkan perbedaan persentase yang tidak terlalu mencolok yaitu berada pada kisaran 13\%. Setelah kedua kelas diberikan perlakuan yang berbeda dengan media PhET untuk kelas MIA 3 dan alat peraga untuk kelas MIA 1 dalam menguji media mana yang lebih efektif digunakan sebagai media pembelajaran dalam praktikum getaran harmonik sederhana, maka diberikan pos-test. 
Nisbayanti, Aisyah Novianti dan Nurul Astuti Rahmadani
Dampak Penggunaan Media Phet dan Alat Peraga Praktikum terhadap Pemahaman Konsep Getaran Harmonik Sederhana pada Siswa SMA
Persentasi yang diperoleh menunjukkan hasil yang berbeda yakni kelas X MIA 1 dengan media alat peraga ternyata lebih tinggi dibandingkan media dengan kelas yang menggunakan media PhET, yaitu kelas X MIA 3.

Berdasarkan hasil uji hipotesis menunjukkan bahwa tidak terdapat perbedaan pemahaman konsep antara kelas yang menggunakan media PhET dengan kelas yang menggunakan media alat peraga praktikum. Sehingga bagi sekolah yang memiliki keterbatasan dalam penyediaan alat peraga dapat menggunakan media PhET sebagai alternatif dalam kegiatan praktikum. Hasil yang didapatkan dalam penelitian ini tidak sejalan dengan hasil penelitian yang dilakukan ref [3] yang menyatakan bahwa hasil belajar siswa yang menggunakan media PhET Simulation lebih baik dari pada hasil belajar siswa yang menggunakan alat peraga praktikum.

\section{KESIMPULAN}

Hasil penelitian menunjukkan terjadi peningkatan pemahaman konsep pada kelas yang diberikan media PhET. Hasil penelitian menunjukkan terjadi peningkatan pemahaman konsep dengan menggunakan media alat peraga praktikum. 4. Berdasarkan analisis dengan CRI, kelas yang menggunakan media alat peraga memiliki persentase pemahaman konsep yang lebih tinggi sebesar 32,75\% dibandingkan dengan media PhET sebesar 24,44\%. Berdasarkan uji hipotesis diperoleh tidak ada perbedaan antara pemahaman konsep peserta didik yang diajar menggunakan media PhET dengan media alat peraga praktikum.

\section{DAFTAR PUSTAKA}

[1]. OECD. 2018. Programme for International Student Assessment (PISA). https://www.oecd.org/pisa/publicati ons/. Diakses pada 1 Mei 2020.

[2]. Pujani, N.M. 2014. Pengembangan Prangkat Praktikum Ilmu Pengetahuan Bumi dan Antariksa Berbasis Kemempuan Generik Sains Untuk Meningkatkan Keterampilan Laboratorium Calon Guru Fisika. Jurnal Pendidikan Indonesia: 3(2): 471-484.

[3]. Aprilia, S., Syuhendri dan Adriani, N. 2015. Analisis Pemahaman Konsep Mahasiswa Program Studi Pendidikan Fisika pada Pokok bahasan Gerak Harmonik Sederhana. Di dalam: Wiyono, K. dkk. Prosiding Seminar Nasional Pendidikan Inovasi Pembelajaran Fisika, IPA dan Ilmu Fisika dalam Menyiapkan Generasi Emas 2045: Palembang. 24 Oktober 2015.

[4]. Direktorat Jenderal Pendidikan Anak Usia Dini, Pendidikan Dasar, dan Pendidikan Menengah Kementrian Pendidikan dan Kebudayaan. 2019. Data Pokok Pendidikan Dasar dan Menengah. https://dapo.dikdasmen.kemdikbud. go.id/. Diakses pada 1 Mei 2020.

[5]. Kementerian Pendidikan dan Kebudayaan Pusat, Data dan Teknologi Informasi. 2020. Statistik Sekolah Menengah Atas (SMA). http://publikasi.data.kemdikbud.go.i d. Diakses pada 1 Mei 2020.

[6]. Purwanto, Eko, A. dkk. 2016. Studi Perbandingan Hasil Belajar Siswa menggunakan Media Phet Simulation dengan Alat Peraga pada Pokok Bahasan Listrik dan Magnet di Kelas IX SMPN 12 Kabupaten Tebo. Jurnal Edu Fisika: 1(1): 2227. 
Nisbayanti, Aisyah Novianti dan Nurul Astuti Rahmadani
Dampak Penggunaan Media Phet dan Alat Peraga Praktikum terhadap Pemahaman

Konsep Getaran Harmonik Sederhana pada Siswa SMA

[7]. Sanidi, S., Ishafit, I., \& Dwi, S. 2015. Prosiding dari Pertemuan Ilmiah XXIX HFI Jateng \& DIY. Peningkatan Pemahaman Siswa Kelas XI MIPA SMA Negeri 1 Krangkeng pada Materi Gerak Harmonis Sederhana Melalui Media Virtual Lab. Hal: 239-243

[8]. Ropandi, A. 2017. Pengembangan Instrumen Three-Tier Test untuk Mengidentifikasi Miskonsepsi Siswa SMA pada Pokok Bahasan Gerak Harmonik Sederhana. Bandung: Universitas Pendidikan Indonesia. 